\section{OPEN $\bigcirc$ ACCESS}

\title{
Identity reconstruction among people with physical disabilities practising Race Running
}

\author{
Authors' contribution: \\ A) conception and design \\ of the study \\ B) acquisition of data \\ C) analysis and interpretation \\ of data \\ D) manuscript preparation \\ E) obtaining funding
}

Received: 17.07 .2021

Accepted: 10.08 .2021

\author{
Radosław Kossakowski*A,C,D (D), Maria Witecka-Wiese ${ }^{\mathrm{A}-\mathrm{D}}$, \\ Dobrosław Mańkowski ${ }^{C-D}$ iD \\ University of Gdańsk, Poland
}

*Correspondence: Radosław Kossakowski, Institute of Sociology, University of Gdańsk, Bażyńskiego 4, 80-309, Gdańsk, Poland, radoslaw.kossakowski@ug.edu.pl

\begin{abstract}
The main aim of the article is to present the results of research concerning the reconstruction of the identity of people with disabilities who practice Race Running. In the scientific literature focused on disability, sport is presented as one of the important elements serving for the reconstruction of the identity of people with disabilities and their integration, inclusion with the surrounding social world. However, previous studies did not analyze in this context the role of Race Running, which is a niche, developing sport discipline. Therefore, this article fills a significant gap in the scientific literature dedicated to the role of sport in the reconstruction of the identity of people with disabilities by undertaking an analysis of sport, which has not been the subject of research so far. Starting from the concept of 'pendulum' developed by Karen K. Yoshida, the following article provides a model of identity reconstruction based on five processes: Socialising, Becoming independent, Exposing, Proving, Realizing. The conceptualization of this model is based on the results of qualitative research using the in-depth interview technique. The respondents were people with disabilities practicing Race Running in Poland, their family members and their coaches. The results of the research show not only the possibilities for people with disabilities, which comes with practicing Race Running, but also limitations, because the specificity and technical requirements of this sport mean that its benefits can only be used by people with a certain type of disability.
\end{abstract}

Key words: Disability, sport, identity, race running, qualitative methods

\section{Introduction}

For many years, various dimensions of disability have become a subject of reflection of the humanities and social sciences. Not only are the social contexts of disability being studied (Ostrowska, 2009), but so is, e.g., the construction of the term itself and the phenomenon of disability (Zdrodowska, 2016). Very often, disabilities tend to be described in the context of exclusion or the stigmatisation of people with disabilities (Fajfer-Kruczek, 2015). In this context, numerous studies (especially those related to social pedagogy or social work) analyse the methods of social integration and the inclusion of people with disabilities (see Korzeniowska, 2018). The analyses of sport as a certain platform of inclusion for people with disabilities have also become an important part of the scientific literature (Kiuppis, 2018). It should be emphasised that, in the scientific literature, the relations between sport and 
disability are analysed multidimensionally. It started with the description and significance of the paralympic movement (Howe, 2015) and broadened to include the existing paradox of visible/invisible sport and the visible/invisible disability of athletes (Purdue and Howe, 2012). This is followed by an analysis of this relationship in the context of media images, gender, and exclusion (see Coakley and Pipe, 2014). In the Polish scientific discussions, there are also publications related to the sport of people with disabilities (Niedbalski, 2017).

An important branch of research, albeit still 'unsaturated' in a sense, involves the topics of identity reconstruction, one's self-definition, and the perception of one's own disability in the context of sport. An interesting paper was written by Andrew C. Sparkes and Brett Smith (2003), who describe the reconstruction of the identity of athletes who have experienced spinal cord injury $(S C I)$ and had to adjust to a new identity as people with disabilities. Another interesting position in the subject literature, in the context of narrative studies related to disabled athletes, is the paper of Chin-Ju Huang and Ian Brittain (2006), addressing the issue of the role which an international success can have for people with disabilities, particularly referring to the potential of the changed subjectivity and the understanding of oneself, along with the strengthening of one's own 'self'. On the other hand, Nikki Wedgwood (2014) in one paper points to the generation and negotiation of one's identity by male athletes with disabilities in relation to the hegemonic maleness functioning in the society. A key role is played in his study by gender and disability in the context of constructing and negotiating oneself by an athlete. In the Polish context, these subjects are addressed by the research of Jakub Niedbalski, who has analysed the issues of causation, subjectivity, and work on oneself of the people with disabilities who practise sports (2016).

In our research, we decided to address the personal observations and experiences of the respondents, which were a foundation for analysing changes in the identity of people with disabilities. It was important to us to look at disabilities and people who struggle with them from a micro-social, identity-based perspective, focusing on an individual and their closest surroundings. This was done using a 'lens' which is the area of sport (Nosal, 2015), and in this case, the sport of people with disabilities. To this end, we performed research of an exploratory nature among people with physical disabilities, suffering from cerebral palsy. They have discovered a sport which has changed their previous lives - Race Running. The individual stories of specific people have allowed us to learn in detail about the reconstruction of identity among people with disabilities, caused by the practising of the sport known as Race Running. Due to this physical activity, people with disabilities have a chance to adopt a schema which is entirely different from the commonly known one, in which a disability constitutes the centre of an individual's life, determining every aspect of their life and everyday functioning. Therefore, the main objective of the article is to analyse the process of reconstructing the identity of people with disabilities who practise Race Running.

The model of reconstructing the identity of people with disabilities developed by Karen K. Yoshida (1993) was the theoretical inspiration in our research. It proposes the conceptualisation of identity reconstruction by means of the 'pendulum' metaphor. It describes the constant process of 'swinging' the identity from the disabled aspect of oneself to a capable 'self'. It is based on five dominant images of identity, which are the result of work on its reconstruction: the previous 'self', the supernormal 'self', the disabled 'self' as a total 'self', the disabled 'self' as an aspect of the total 'self', as well as the balanced 'self'. These images of oneself are the consequence of experiences which form a holistic process starting from a loss (the loss of ability), going through the reaching of balance, integration, continuity and the development of oneself. In short, in the event of losing ability (due to an accident, a disease, etc.), a given case may be interpreted by means of the metaphor of a moving pendulum: a person with a disability experiences such movements towards one side - the feeling of ability - and the other side - the return to disability. This entire 'swinging' process of the pendulum is variable over time, since during the identity reconstruction process, the 'swings' return to already different images of one's (dis)ability.

Our study shows that the identity reconstruction process can also be considered as such: as a process, in which the 'pendulum' of identity swings to one and to the other side, but along with the passage of time and, e.g., the advancement of sports training, the given person is already a 'different' person, with a different image of oneself although still experiencing all the consequences of living with the disability. Our research indicates that this identity reconstruction process is based on the model of five mechanisms: socialising, becoming independent, exposing, proving, realising. The following dimensions have a broader significance than in the case of Yoshida's concept, since in it the context of identity also comprises the social space, not just the individual one. This is because there it takes on the perspective of symbolical interactionism, which points to the social, interactional context of acquiring and maintaining an identity (Blumer, 2007). However, due to the fact that the identity reconstruction process discussed in the text also has an awareness-related dimension in a sense, a phenomenological one as it were, the analytical frame of symbolical interactionism is strongly supported by the interpretational perspective. The interactional and interpretational nature of our analyses is also related to the fact that we attempted to understand the 
processes of reconstructing the identity of the studied people based on not just their experiences revealed when interviewing them, but also on information from the people close to them (parents, coaches). Therefore, we wanted for the knowledge about the social components of our model to also originate from those respondents who witnessed the development of these socialised dimensions.

The present article has been divided into the following parts. The first one will present a short characterisation of basic issues related to disability and the sports of people with disabilities. The next part presents the methodological details of work, while the following one analyses empirical data used as a basis for distinguishing five processes influencing the reconstruction of identity. The article ends with a discussion and summary.

\section{Disability}

The subject of defining disability both in a scientific discussion (Niedbalski, 2019) and in social perception raises numerous controversial issues. It is very difficult to define the term physical disability, due to the multidimensionality of this phenomenon. In addition, the matter is complicated by the existence of numerous definitions of disability constructed in various sciences: pedagogy, psychology, sociology, medicine or law (Bieganowska, 2015; Urbanowicz, 2012). Differences in terminology also result from the evolution and changes in the manner of perceiving people with disabilities over the centuries (Giełda, 2015).

In this context, one should also remember about language issues. This is because it is very important to talk about people with disabilities, and not 'disabled people'. Calling someone 'disabled' encloses this individual within their disability and constructs them as a person defined only by a single feature (Galasiński, 2013) - disability, which distorts the perception of the given individual in the context of the other roles played by them. Therefore, in the light of the above, the language can be a source of stigmatisation, since it is a tool which shapes our reality (Grabias, 2009), but also allows for the self-definition of individuals (Skibiński, 2018). In terms of our research, it was the self-definition and redefinition of one's own 'self' that was of key significance, also taking place, e.g., at the language level.

The term 'disability' is a very broad one, covering a wide spectrum of dysfunctions of the human body. It replaces numerous previous definitions which were generally accepted by the society, such as: handicap; impairment; frailty; infirmity; invalidity; and which took on a pejorative meaning when functioning in everyday language. As stated by Jakub Niedbalski (2017, p. 25):

"The image of a disabled person as someone dependent, defenceless, unable to independently take care of themselves and their own interests, in other words, the image of a person different from the rest of the normal society, is being replaced with an increasing frequency by the image of a person who constantly encounters barriers created by this normal society. Those very barriers, and not the features of people with disabilities, constitute a main obstacle in functioning on an equal footing in the society".

In the context of the research described below, it was interesting to see what obstacles and barriers emerge in the way of people struggling with a specific type of disability known as cerebral palsy, and in what way these barriers are overcome by sport. It should be noted that cerebral palsy is described as a neuromotor disorder which affects the development of motor skills, muscle tension and posture. This illness is brain pathophysiology, which means damage to a developing brain during a time from the prenatal period until infancy. It affects a number of secondary ailments, which in various ways affect the functional skills of a child (Patel et al., 2020), and over time - an adult.

The emerging dysfunctions are related primarily to the ability to move. Problems with motion can manifest themselves in various ways and with different intensities. Certain people have problems with stable walking, and for them it is necessary to adjust proper footwear, while others cannot move by themselves at all, and it is necessary to use a wheelchair or a special equipment replacing independent walking. Therefore, the group of people with such a diagnosis includes both those who function independently, as well as those who require constant care in daily activities. Frequent symptoms of cerebral palsy include excessive muscle tension, meaning the so-called spasticity (excessive muscle tension), athetosis (involuntary slow movements of the upper limbs) and ataxia (problems with coordinating body movements) (Patel, et al. 2020).

From a sociological standpoint, the social functioning of people with cerebral palsy is strongly conditioned by culture, and it can largely depend on external social conditions (Niedbalski, 2017). Disability is a phenomenon which can be studied and defined through medicine, biology or psychology, but it should be kept in mind that it is also a social phenomenon and the creation of everyday interactions. 


\section{Sport and disability}

Sport for people with disabilities can become a source of new possibilities of fighting the stigma and stereotypes related to passiveness and 'frailty'; it is also related to the broadly understood motor rehabilitation (Koper and Tasiemski, 2013). Physical activity has been recommended by doctors for many people, in particular those after various types of accidents, or wounded war veterans. Therefore, initiatives related to the sport of people with disabilities were initially considered a recommended form of adaptation, as well as of supporting and improving physical fitness. Over time, with the emerging desire for rivalry and for proving one's abilities compared to other competitors, first Special Olympics Games were organised in the United States. In Poland, the Polish Sports Association for the Disabled 'Start', active since 1952, is one of the first organisations which began to bring together people with disabilities practising sport.

In order to help disseminate and promote the idea of paralympics and the sport of people with disabilities, the Polish Paralympic Committee was also established in 1998. It supports people with disabilities who are preparing to participate in Paralympic Games. Principles and rules of competition were established in the institutional dimension of sports of people with disabilities. The effective categorisation of competitors into start groups according to medical and functional criteria enables people with disabilities to compete on equal terms. In order for this rivalry to be as equal as possible, it is necessary to precisely define and determine the degree of disability with which every competitor is struggling.

In the processes of shaping and reconstructing the identity of people with disabilities, key significance is attributed to contacts, interactions and bonds with other people. Particularly important are the so-called 'significant others' (Berger and Luckmann, 1983), meaning the people whose opinions mean the most to us, since for some reasons they are exceptionally important and close to us. In our study, we decided to take a look at two groups of significant others, who include the parents and the coaches (or physiotherapists). Usually, particularly intensive and emotional bonds connect an individual to the parents, or to people who are an authority to them. For people with disabilities, significant others are so important that sometimes their assistance is critical in their daily functioning.

"In the face of the experienced disability, an important part is played by the closest people, the so-called first circle of support. It is them who can constitute specific support for people with disabilities, which allows for overcoming the negative consequences of the emergent disability”. (Zielińska-Król, 2014, p. 80)

The practising of sports by people with disabilities makes a given person meet a larger number of people, not limiting their contacts just to the family circle. Because of the training, the contact with coaches and other competitors proves equally important. Collective exercises, trips and meetings cause the circle of people with whom the individual interacts directly to constantly grow. Membership in a certain, specific group, with similar interests and a similar life situation, can also contribute to the creation of collective identity. Entering the group is often associated with adopting established standards and customs which govern it. Therefore, collective identity manifests itself through identification with the group to which the individual belongs, and by referring to it as 'we', e.g., 'we the athletes', 'we the runners'. According to Jakub Niedbalski:

"The creation of a group, apart from the obvious consolidation of its members around the issues of broadly understood sport, also proceeds based on the shared situation in life, related to the inherent dysfunctions and the needs resulting from them. In this way, sport can serve a particularly important function in the socialisation process of an individual, becoming the stronghold of their emerging faith in oneself and one's capabilities, and the contact with people having similar problems and dysfunctions, who practise the given discipline, can strengthen their assurance about their own hidden abilities". (2017, p. 46)

The coaches and physiotherapists of people with disabilities also play an important role. Parents are not always able to motivate and mobilise their children to exercise or compete, like the coaches and physiotherapists do. Their authority and proper approach are responsible for motivating an individual to act and achieve the best possible results. Every success in sport or rehabilitation, even a small one, contributes to the increasing self-acceptance and awareness of one's body. In the case in question, this sport, in which people with disabilities participate, is the aforementioned Race Running.

\section{Race Running}

This sport was created in the 1990s in Denmark. It was invented by a Dane, Mansoor Siddiqi, along with an athlete, Connie Hansen. Mansoor, who was/is a disabled person, asked Hansen for help in designing a 'vehicle' which would help him move normally. Due to the deformation of his body, Mansoor was previously forced to 
only move backwards in a wheelchair. The first handicap tricycle (also known as a 'mobiler') was assembled by him from various spare parts, such as the backrest of an office chair and a pipe from an old vacuum cleaner. Although, as the years went by, the shape of the mobiler changed, work is continued to this day to give it a form which would make it as comfortable and manoeuvrable as possible. Each mobiler must be adjusted to the weight, height and type of illness of a person with a disability. As the work progressed, it turned out that this tricycle, not having pedals, was a great combination of sport and rehabilitation. Moreover, it can be used by anyone, even people with severe motor disabilities (such as in the case of cerebral palsy). Therefore, the mobiler serves many functions related not just to sports and rehabilitation, but also to the social aspect. The phenomenon of Race Running is in that it is a combination of sports and rehabilitation, which in a way takes place 'by the way' during walks and sport achievements. Besides, it is something completely new in the tedious process of exercises and physiotherapeutic massages. This sport is a discipline based on strength and stamina, which enables intense physical effort of people who in their everyday lives only move using electric wheelchairs or walkers. Race Running coaches ensure us that it can be practised by virtually anyone who struggles with disabilities. Mobilers are recommended to anyone whose one lower limb is at least slightly functional. They do not work only in the case of a total paresis or a deep mental disability.

The rules of this sport are based on the running of competitors in mobilers around a running track. Each runner uses a tricycle without pedals - moving by pushing their feet against the ground. In order to make it possible for people with a wide range of disability, one must take a proper position, which means leaning their torso against a special support, at the same time resting on a typical bicycle saddle. The propelling force then comes from the legs and the body weight. The hands in turn have to be on the handlebar, on which the brakes are mounted. In order to steer it, one does not have to be two-handed - it is possible to steer the mobiler using one hand only. The handlebar does not turn by itself, and after each curve it returns to its place in a rectilinear position. Therefore, there is no risk of the tricycle suddenly turning and causing an accident. It is a very safe design.

\section{Own research methodology}

The objective of the research performed by us was to reconstruct the mechanisms through which Race Running influences the process of defining oneself and interpreting the social reality surrounding an individual. Therefore, we focused primarily on the attempt at tracing the course of identity reconstruction for people with disabilities, who, owing it to handicap tricycles, rediscover themselves, their body, the capabilities and weaknesses, but they also broaden their social capital. The main research question which we presented was: In what way did the practising of the sport which is Race Running influence the change in seeing one's own 'self' in the perception of people with disabilities and their closest surroundings? In order to get an answer to this question, we attempted to reconstruct the significance of physical activity and practising sports, which plays a very important role in the process of shaping the identity of an athlete with a disability.

In our study of people with disabilities practising Race Running, we used a research perspective associated with an exploratory case study (Yin, 2014). On the one hand, the application of such a research concept allows for creating a foundation for further in-depth studies on constructing and redefining the identity of people with disabilities who practise sports. On the other hand, it enables a thorough examination of this process based on the selected case of people with disabilities - cerebral palsy - practising Race Running.

In the case study, we used methods from the range of qualitative studies, which allow for reaching the subjective experiences, impressions, emotions and observations of the studied social actors. Therefore, we focussed on individual experiences, which influenced the biographies and the adopted identities of the subjects (Hałas, 2006). In the selected method, it was crucial to identify the subtle nuances, which according to the people with disabilities can have a strong impact on the shaping of the feeling of one's 'self'. The greatest challenge was to choose and filter the research subjects. As stated by Krzysztof Konecki (2000, p. 126):

"A case selected for research should be clearly distinguishable as a certain system, and the actions observed in it should proceed according to clearly reconstructible patterns. Clear boundaries, or behavioural patterns, are the key elements which enable understanding the given case".

The isolated research group originated from the 'Zabajka' rehabilitation centre in Złotów, and it consisted of 3 people with disabilities (two women and one man in an age interval of 18-25 years who practise Race Running and have achieved great successes in this area). These conversations were complemented by interviews with their 
parents and coaches. The initial assumption was to perform biographical interviews with people with disabilities, which would allow for a precise identification of the course of changes in their identities. However, it turned out that, due to various objective reasons and limitations (primarily resulting from the physical condition), the people suffering from cerebral palsy were not able to respond to all our questions, despite their best intentions. To us, it was a very interesting experience, which made us even more aware how hard it is for people with disabilities to be listened to. Therefore, we decided to perform individual, thorough free interviews.

The pattern of the interviews was created in a manner which would be as flexible as possible, and adjusted to the people with disabilities who participated in them. The questions asked were adjusted to each respondent individually, based on the degree of disability. Moreover, the questions allowed for the discernment of 5 most important themes, which in the analysis were called the five mechanisms. This is why the analysis was divided into five parts, and each one of them delved into a diverse range of subjects related to reconstructing the identity of the interviewed people. The main analysis focused on 11 interviews, which consisted of three individual conversations with people with disabilities, three individual interviews with the parents, three individual conversations with female Race Running coaches, and an interview with the Director of the Złotowianka Foundation and with the main instructor and Race Running representative in Złotów. Apart from the performed interviews, the collected data were supplemented by performing a desk research analysis (Bednarowska, 2015). This research technique was applied to analyse research articles, research reports and individual biographies and books related to the selected subject.

\section{Research results}

Race Running is primarily a sport which proves to people with disabilities that anyone, regardless of the age, gender or type of disability, can find for themselves a sports discipline in which they would become the best. The matter of discovering one's own potential means proving to their own 'self' that the image of disability constructed by the society does not have to be associated with a passive lifestyle. This is adequately described by a statement from one of the coaches:

“(...) imagine that, say, you are suddenly an astronaut. And what are you thinking in your head? Gosh, I did not go through a NASA school, yet all of a sudden I'm an astronaut! And I flew to the moon. And they [Race Running competitors - author's note] are astronauts of sorts, since some of them immediately become the champions of Poland or break world records". [Respondent 7]

Therefore, when analysing the collected material, we were trying to understand and describe the way in which the sport that is Race Running contributed to the process of redefining oneself and interpreting the social reality surrounding an individual. The reconstruction of identity is a complex and individual process, which is related to an individual experiencing oneself both as a subject, but also as an object, becoming the focus of one's own observation (Bokszański, 2005). Since childhood, all respondents were the patients of the rehabilitation centre. When the Race Running section was established in it, they started to train regularly and began to perceive themselves and their capabilities in a completely different way. They turned from being patients to being athletes. During the conversations, it was possible to distinguish 5 common areas which, because of the practising of Race Running, had the greatest impact on a change in viewing one's own 'self' in the perception of people with disabilities and their closest surroundings.

\section{Socialising}

The first area was the socialisation of people with disabilities, who because of physical activity increased their social capital and relationship networks. The very fact of belonging to a certain group of athletes grew in them a strong feeling of collective identity. Full acceptance by the group, the feeling of understanding and the shared passion related to Race Running caused the respondents to become self-confident and develop lasting friendships. The addition of new 'significant others' is directly related to redefining one's own 'self'. All our interlocutors claimed that socialisation influenced the change in their perception of themselves in the lives of people with disabilities. From the somewhat shy and withdrawn people who led rather passive lifestyles, they became more open to new relationships and curious for new experiences. For each one of the respondents, the process of socialisation was completely different. However, all of them noticed a very positive change in their development of social relationships: 
"I opened up to the world. All in all, I opened up to the people more. As I was always a rather withdrawn person, and I feel this makes me feel good. So they are such positive changes. I simply opened up to the people more, I met new friends and I am very happy about that". [Respondent 1]

Socialisation through sport is also related to rivalry. For many competitors suffering from disabilities, the trainings are a certain form of proving one's abilities among their peers, but also a form of self-appreciation. Therefore, the coaches strongly emphasise good relationships with the competitors, which was noticeable in numerous statements:

"Race Running is such a discipline which not only provides improvement in terms of the very fact of perfecting one's performance as regards rehabilitation, but it can also create an excellent atmosphere around every competitor. (...) We, the competitors, form something like one family with the coaches, which is actually impossible to describe, impossible to surpass". [Respondent 3]

One competitor in particular emphasised the strong significance of the group which he has been considering his family ever since he started training Race Running:

"I am very pleased that I can meet with people like them; I can interact with this community, since this is such a community where everyone has their own difficulties in a way, but everyone feels support. The support of both a fellow competitor as well as all coaches. And the coaches do their best at their work, since it is not easy work-working with disabled people. And they are suited to this, in a way”. [Respondent 3]

In his case, it was the fact of belonging to a certain social group and identifying with it that had the greatest impact on a change in his perception of himself. On multiple occasions, he emphasised the gratitude he feels towards the coaches and the competitors:

“(...) I am very glad that I also belong to this group. And I am grateful to all coaches, no exceptions, for how much effort they put into each individual competitor. But also in terms of the group. They give their best, and maybe even more. (...) And every competitor feels that there is such a bond with every coach. For example, you can tell your coach that you cannot make it at a training. When a coach sees that... that you can't make it, then... they themselves say 'let go' to a competitor. And if the competitor is tired, but the coach sees they are... that something can still be done, they always motivate us, and when there is a difficult period, the coach is always with the competitor and always motivates them". [Respondent 3]

\section{Becoming independent}

The second aspect of working on identity was to become independent and feel the self-determination of one's fate. Unsupervised trips (without parents) to the competitions were an opportunity to get to know one's own 'self' from an entirely different side. New conditions, new situations and new social interactions contributed to the reconstruction of one's own identity and self-perception. The very decision about pursuing the sport was also of key significance. The commencement of Race Running trainings was a first step towards independence - at the level of a decision about attempting to experience something new. Moreover, the shaping of one's own inner motivation for exercises and trainings was the next step towards greater autonomy. Prior to that, rehabilitation exercises were a cumbersome necessity; now the body undergoes rehabilitation 'by the way' as it were, when practising Race Running, helping to 'stand on one's own feet' for the first time - even for people who spent their whole lives moving only in a wheelchair. The first training was often described as a breakthrough experience in the respondents' lives. Especially for the parents, it is a very touching moment when their children make their first steps on their own. As mentioned by one of the coaches:

"I cried during the first training. I mean the tears rolled by themselves, because I was touched. Initially, during the competitions I could not look at all at the parents, who are happy about this victory and because their child stands on their own feet. This is so touching. They would never think that their child would stand at the start line, never mind winning the competition. This is like, I don't know... to me it's a great experience. Well, I can't stop this emotion and I'm bottling it all up, to not get soppy. This gives me a lot of joy"”. [Respondent 9]

In the context of becoming independent, a very important matter had to do with the first trips to sporting events, during which the competitors with disabilities took their own steps by definition, as it were. A trip took by oneself requires numerous quick autonomous decisions and finding oneself in an entirely new, previously unknown situation. Such experiences also have a great impact on changing the perception of oneself. The feeling of coping under 
new, unknown conditions, really bolsters your confidence. One of the parents named the first competition as the most important turning points in the life of his daughter:

"Yes, it was the Polish Junior Championship and it was basically the first trip, a beginning if you will. Paving the way, as it were, (...). I think so. And this was where she won her first two medals. 100 metres and 200 metres. They were two silver medals and her total beginning. First starts and first two medals. And I guess these medals were maybe the most important, the most significant. Because it's obviously something that gives you a lot of this good motivation". [Respondent 2]

For the parents of people with disabilities, a trip of their child by themselves is a new situation, albeit not an easy one to get used to for everyone:

Respondent: I mean, it was hard for me, but I knew she had great care. I was most worried about this travel. Because once I learned that they got there, I was OK. I was supposed to join them there, arrive two days before their return, but I figured it would be a waste of my time and money and everything. Because she was doing great in there. And she could manage those three more days without me. So I said, let her stay there by herself and that's fine.

Researcher: And how did she take it?

"Respondent: Great. She said it was the best trip in her life and there was no problem at all. (...) finally I let her go somewhere (laughter). She's rather dependent. We are still learning this. But she is still so clumsy and I'm trying not to help her. But this is always at the back of my mind. This and the medicines which she takes two times a week. These pills she takes, I must give them to her with this cheese and, well, this is not that simple. I don't want to oblige someone to, well, to have to do this". [Respondent 6]

Therefore, in this context, it should be mentioned that increasing the independence of people with disabilities leaves its mark on their social surroundings, since this is also a challenge for the parents, the coaches. Therefore, reconstruction of the subjects' identity cannot be analysed in separation from interactions with the others.

\section{Exposing}

In the course of research, we noticed that among the respondents, the sport accentuated the great need for selffulfilment of the people with disabilities. Exposing was another, third theme of the inner change. It can be considered as a need to find one's place in the social space and show that people with disabilities are also a part of it. The desire to be noticed, taken under consideration, is a kind of a fight with the stigma (Gofmann, 2005) and with the exclusion of people with disabilities from social life (Fajfer-Kruczek, 2015). Race Running provides the possibility to go beyond the limiting and stereotypical patterns which assume that sport is not for people with disabilities. People who get up from wheelchairs and run on mobilers are a proof that this is not the case.

"A lot of these mothers come here and simply thank us and indeed cry, saying 'Jesus, it's so good you're around. It's so good that you came up with this, because this changed the lives of these kids'. Actually, they are no longer kids, but adults. But, you know, when someone only sits at home and stares at the computer, and whatever they want to touch, they are not suitable for it, since their physicality limits them. It is hard to find a sport which would be available to these people at all. And suddenly, Race Running appears and they find fulfilment here. So this is really amazing... “ [Respondent 11]

Exposure can be considered as gaining the respect of significant others, as well as in a broader context. Recognition of sorts, esteem and appreciation of the first sports achievements is very encouraging. Especially when the previous experiences of people with disabilities were largely related to being rejected and discriminated against by the society:

“(...) sport is an area which gives you an opportunity to cope with defeat. But also to reach certain goals. And through this, you can try to look for the upsides. Prove to yourself that you can, in spite of the disability. And since I can do something, this means that it's worth pursuing, that it is good. And because of that, this feeling of appreciation is stronger. And the reception is more open to others, that one will not face only criticism once again. Or some kind of rejection". [Respondent 2]

All the respondents greatly appreciated the fact that they had been noticed by the coaches, thanks to which today they have an opportunity to participate in contests. 
"I am very pleased with the fact that the coaches trusted me, that they gave me the chance to compete in numerous contests. I hope that such cooperation will continue to progress so well, as they really are amazing people. Because, being a disabled person myself, I had never even heard of such a sport”. [Respondent 3]

The above respondent considers the competition as a certain form of revealing oneself and proving to others that disability does not preclude from playing many other social roles in life, e.g., being an athlete. For this competitor, trainings in the urban space are also a form of exposing oneself. As mentioned by his mother, the son's training in the streets of Wrocław impresses the others, therefore strengthening the 'exposing' effect:

"Well, and the very fact that when we go out in Wroclaw to run in the city, I can say that this tricycle impresses everyone. Everyone stares at this tricycle. And for now he is the only one in Wroctaw who has this tricycle. And we want to work in this very direction. I even asked about Race Running coach courses. We would like to do something. Well, and my son even e-mailed the mayor of Wrockaw about it. He's already arranged a meeting (laughter) (...) in a week he's going to the mayor of Wroctaw to ask whether he will get any support from the city, because he wants to establish a Race Runing section in Wroctaw”. [Respondent 4]

So, the mobiler caused this competitor to start to leave home more eagerly, attracting quite the attention of bystanders when doing so. Race Running fascinated him so much that he felt a strong urge to act in this direction. His involvement in the promotion of this sport is the best example of how important it is to people with disabilities to be exposed and to find their place in the social space.

\section{Proving}

As the fourth theme of the analysis, proving is related to exposing. This is because people with disabilities try to prove through sport not only their presence, but also their value. This means proving to the parents, the coaches and the whole society that people with disabilities also can spend their time actively and pursue their passions. They can compete in contests and even break world records. This also means proving to oneself that disability does not preclude being an athlete and fulfilling oneself through sport. Like most sports, Race Running proves that life is a roller-coaster of failures and successes, which are a series of life experiences. Achievements in sport and the acknowledgement of the 'significant others' are a source of satisfaction which makes up for the whole effort:

"In there, everyone simply cheers for her, congratulates her. Always. So she is so very proud every time she returns from a contest. Regardless whether she won the third prize or none at all, but it is really great. The whole family cheers for her. She hangs her medals in the room. And it gives me joy when I have to drive her to this training and see how she trains there”. [Respondent 6]

Proving to the parents and to the caretakers that one is capable of breaking sports records in spite of the high degree of disability brings great joy not just to the competitors, but also to the people from their nearest surroundings. This is often a matter of ambition and proving also to oneself, that even with disabilities the body can be a tool for achieving successes in sport, and it can endure more than it could seem:

"I am in this section, and I am actually very happy that I can be such a person who simply betters herself. ... Race Running is such great satisfaction to me, because one can also feel such joy. This also requires plenty of such physical labour and methodicalness. Precisely the feeling of such adrenaline, and this is very nice. Really". [Respondent 1]

Also, another competitor said something similar:

"What has changed in my life is that, for example I can... I can use my disability in a sport, in which I have some chances. Because I think my chances are big. My disability is a type of disability which can help me in this sport. And the very fact that Race Running makes me feel like such a person... how should I say... One who... who actually can achieve something in life. Like, I don't know, win medals. And at that while being surrounded by friends and people who are devoted to this sport in 100\%, as it were". [Respondent 3]

This respondent also emphasised that running with the mobiler made him feel pride for the first time in his life. Never before has he imagined that there would be a sport which would be a space in which he could find satisfaction and fulfil himself. As he adds:

"After the contest, I felt joy and the feeling of such fulfilment related strictly to sport, that I could win this medal by my hard work, but also because of the persistence in sport, which was actually shaped in me by Race Running. [trembling 
voice, tears of emotion]. I felt something like... such an inner need, pride that I managed to do something. Because before that, I thought that this disability of mine is a hopeless type, with which I cannot achieve anything. And which in a way shuts the door to sport for me". [crying] [Respondent 3]

The statement of this competitor which caused his emotional tears proves how important an issue self-fulfilment is for the people with disabilities. In the case of this respondent, the desire to prove one's strength has also been confirmed by one of his family members:

\begin{abstract}
"At every competition, he has a lot of emotions. Mostly such positive ones, related to sport. Such sport fighting awakens within him. The second case was a $400 \mathrm{~m}$ run. He is generally a sprinter. Not long distances, only such short and quick ones. But they actually let him run $400 \mathrm{~m}$ in Bydgoszcz, and I can say that during the final lap I could tell his legs were aching horribly. He skinned these legs, the blood was pouring, he had no more power and he was crying, but I saw he was in two minds and he kept thinking that he had to run the whole distance. He had to finish the race, because the coaches, the parents and everyone was looking. And everyone, the entire audience, were cheering for him. They were screaming. And so he made it, but on his last legs generally. The leg was damaged, the blood was pouring. And when we got him off the tricycle, he simply fell to the ground. He was exhausted and happy. It awakens such emotions in him, such sports ambition, really. Just to finish the race, not to give up. And this is great for him, since he keeps defeating himself. He is overcoming his weaknesses at this moment. So I think that because of this he also feels so good about himself". [Respondent 4]
\end{abstract}

Overcoming one's own weaknesses in this case is the matter of ambition, which is sometimes related to extreme experiences, like injured legs and complete exhaustion. Due to the adrenaline, only the goal matters, which is to reach the finish line. Such an experience, in which you cross your own boundaries and prove (to yourself and the others), that the boundaries are fluid, leads to a change in the perception of yourself and the reconstruction of your identity.

\title{
Realising
}

The realisation of how Race Running influenced the change in viewing oneself was the final, fifth area of the analysis. The realisation of the capabilities of one's body, one's skills, one's determination and the successes achieved in sports so far results in a strong feeling of pride and fulfilment. It is also associated with crossing one's own boundaries, which directly changes the perception of one's own identity. Redefining oneself through sports achievements makes an individual aware of their change. Before the mobilers appeared, moving on one's own feet was impossible for many people with disabilities, or it required many hours of rehabilitation every day, starting already in early childhood:

"I used the Doman technique (...) this is simply a series of sorts. That you go $800 \mathrm{~m}$ on all fours, crawling, in order to finally switch to walk or to run. In order to simply start walking. I really recommend the Doman technique, but it requires much effort. I exercised eight hours a day. And the best thing was, I had this awareness. I mean, as a child I was not aware that I was exercising so much". [Respondent 1]

The abovementioned statement includes the subject of unawareness of the enormous rehabilitation work which constitutes a huge part of the childhood of people with disabilities. This competitor said that it was not until she had grown older that she realised how much time the was spending for rehabilitation. Because of her earlier efforts, today she is much more aware of her body.

Race Running entails numerous positive consequences, not only those strictly associated with sports. One of the competitors noted that sport had made him aware of the weight of various challenges in life.

"Because sport can help a man in such a way that, for example, one can become better and better, fitter, but it can also sculpt the character. And because of the coaches, having travelled to those various Race Running contests, I can see in myself not just an improvement in the aspect related strictly to sports, but that I am, I keep becoming better. And fitter. But also, because of them, those trainings and contests, my character has been moulded in a way". [Respondent 3]

Apart from a change in character, after a victory in the contest, this competitor also went through a great change related to the feeling of his own self. He shaped the awareness of being an athlete, whose inherent attribute is winning medals and starting in competitions: 
"I feel I am an athlete, because I felt I was an athlete just when I won this medal. And then I rode to the coaches and the coaches congratulated me, and it is because of them that I am at such a camp now. This is my second time at such a camp and I don't regret the choice of this sport'. [Respondent 3]

\section{Summary and discussion}

An analysis of the material collected during the research allowed for understanding the way in which the sport that is Race Running can influence the process of defining oneself and interpreting the social reality surrounding an individual. Identity reconstruction is a very complex and individual process. The research allowed for the discernment of five processes which were developed (or strengthened) due to the practising of Race Running, which, as a consequence, influenced the change in seeing one's own 'self' for the people with disabilities and their closest surroundings.

The first area was the socialisation of people with disabilities, who, because of physical activity, increased their social capital and relationship networks. The very fact of belonging to a certain group of athletes grew in them a strong feeling of collective identity. The important acceptance of the group, the feeling of understanding and the shared passion that is Race Running caused the respondents to become self-confident and develop lasting friendships. All of them confirmed that socialisation had the greatest impact on changing their perception of themselves in the life of people with disabilities. From the somewhat shy and withdrawn people who led rather passive lifestyles, they have become more open to new relationships and curious for new experiences. The second important issue was to become independent and feel the self-determination of one's fate. Unsupervised trips (without parents) to the competitions were an opportunity to get to know one's own 'self' from an entirely different side, under new conditions. For the competitors, the very decision to pursue the sport that is Race Running was one of the first independent decisions. The shaping of one's own inner motivation for exercises and trainings was the next step towards greater autonomy. Prior to that, rehabilitation exercises were a tedious necessity, and now the body undergoes rehabilitation 'by the way' as it were, when practising Race Running. The sport caused the rehabilitation process itself, often cumbersome and strenuous, to become more justified, as it became the means to another goal - which was to become an athlete. Therefore, the swinging of the identity 'pendulum' towards the 'capable' self gains an additional component here, in the form of another role - that of an athlete.

Among people with disabilities, sport emphasises the great need for self-fulfilment. Exposing was another theme of the inner change. It can be considered as a need to find one's place in the social space and show that people with disabilities are also a part of it. The desire to be noticed, taken under consideration, is a kind of a fight with the stigma and the exclusion of people with disabilities from social life. As the fourth theme of the analysis, proving is related to exposing. This is because people with disabilities try to prove through sport not only their presence, but also their value. This is proving to the parents, the coaches and the whole society that people with disabilities also can spend their time actively and pursue their passions. They can compete in contests and even break world records. This also means proving to oneself that disability does not preclude being an athlete and fulfilling oneself through sport. On the other hand, the realisation of how Race Running influenced the change in viewing oneself was the final, fifth area of research. The realisation of the capabilities of one's body, one's skills, one's determination and the successes achieved in sports so far results in a strong feeling of pride and fulfilment.

All five areas have contributed to an identity transformation which was accomplished in the case of people with disabilities. Since they joined the Race Running section and they have been travelling to contests, they have started calling themselves athletes. They also changed the way of looking at their disability and their body, which they began to consider a 'tool' for reaching the consecutive goals and breaking the records. This also indicates the swinging of the identity 'pendulum' towards ability, since the consideration of one's body as a tool is something natural in sports. It becomes similar for people with disabilities, which is the advantage of Race Running, since it is the nature of this sport and the used equipment that help to build the feeling of a capable 'self'. This cannot be forgotten; in the case of the studied people, not every sport would serve a similar function. Perhaps - and this is one of the limitations of the conclusions drawn here - other sports (e.g., running) would have a reverse result: they could cause a deepening of the frustration, the feeling of inability to break the barriers of disability, and therefore it could move the identity pendulum even further towards the 'disabled' self. Therefore, the role of sports in reconstructing the identities of people with disabilities should be approached in context, considering, e.g., the technical nuances. Race Running is undoubtedly a sport which enabled the subjects to overcome the limitations and extend their abilities. 
However, this does not mean that the entire process was the same for all the people. In order to verify this, it was therefore necessary to interview the third parties, who could verify the statements about the subjects' identity reconstruction from a distance. Such an approach allowed for acquiring information about the 'dark' sides of such reconstruction, like, e.g., the appearance of haughty behaviour in one person, which complicated their relationships with the others. On the other hand, conversations with the people close to them made it possible to learn about the broader context of identity changes, when, for one of the subjects, the practising of Race Running was a springboard to thinking about the others (the promotion of this sport in a wider social context). Therefore, there is no single answer to the question how the 'self' of the respondents changed due to the practised sport. However, in a general sense, the respondents' narrations indicate that among people with disabilities, sport can be the force initiating the movement of the identity 'pendulum', and although it does not allow for bringing back a fully capable body, it enables the feeling of a capable 'self', which integrates people with disabilities into a broader social context.

\section{References:}

Berger, P., \& Luckman, T. (1983). Społeczne tworzenie rzeczywistości /The Social Construction of Reality/. Translated by Józef Niżnik, Warszawa: PIW.

Bieganowska, A. (2015). Przekaz medialny w modyfikowaniu postaw studentów pedagogiki wobec niepetnosprawności / Media message in modifying the attitudes of pedagogy students towards disability/. Lublin: Wydawnictwo UMCS.

Blumer, H. (2009). Interakcjonizm symboliczny /Symbolic Interactionism/. Kraków: Wydawnoctwo Nomos.

Coakley, J., \& Pipe E. (2014). Sports in society. Berkshire: McGraw Hill

Fajfer-Kruczek, I. (2015). Wykluczenie społeczne osób z niepetnosprawnościq w środowisku lokalnym /Social exclusion of people with disabilities in the local environment/. Katowice: Uniwersytet Ślaski.

Galasiński, D. (2013). Osoby niepełnosprawne czy z niepełnosprawnością? /Disabled people or people with disability?/ Niepelnosprawność - zagadnienia, problemy, rozwiazania", 4(9), 3-6.

Giełda, M. (2015). Pojęcie niepełnosprawności /The idea of disability/. In M. Giełda, R. Rasiewska-Skałecka (Eds.), Prawno-administracyjne aspekty sytuacji osób niepetnosprawnych $w$ Polsce /Legal and administrative aspects of the situation of disabled people in Poland/ (pp. 17-32). Uniwersytet Wrocławski.

Goffman, E. (2005). Piętno. Rozważania o zranionej tożsamości /Stigma: Notes on the Management of Spoiled Identity/. Translated by Aleksandra Dzierżyńska, Joanna Tokarska-Bakir, Gdańsk: GWP.

Grabias, S. (2009). Język w zachowaniach spolecznych. Podstawy socjolingwistyki i logopedii /Language in social behavior. Fundamentals of sociolinguistics and speech therapy/. Lublin: UMSC.

Howe, P. D. (2015). The case of the Paralympic Games. In R. Giulianotti (Ed.), Routledge handbook of the sociology of sport (pp. 251-261). Routledge.

Huang, C., \& Brittain, I., (2006). Negotiating identities through disability sport. Sociology of sport journal, 23(4), 352-375. https://doi.org/10.1123/ssj.23.4.352

Kiuppis, F. (2018). Inclusion in sport: disability and participation. Sport in Society, 21(1), 4-21. https://doi.org/10.1080/ 17430437.2016 .1225882

Konecki, K. (2000). Studia z metodologii badań jakościowych /Studies in the methodology of qualitative research/. Warszawa: PWN.

Koper, M., \& Tasiemski, T. (2013). Miejsce sportu w procesie rehabilitacji osób niepełnosprawnych fizycznie /The place of sport in the process of rehabilitation of physically disabled people/. Niepetnosprawność - zagadnienia, problemy, rozwiazania, 3(8), 11-134.

Korzeniowska, R. (2018). Inkluzja społeczna dorosłych osób z niepełnosprawnością intelektualną na przykładzie wsparcia społecznego /Social inclusion of adults with intellectual disabilities on the example of social suport/. Niepetnosprawność - zagadnienia, problemy, rozwiqzania, 3(28), 97-118.

Niedbalski, J. (2016). Aktywizowanie przez sport jako sposób inkluzji oraz integracji społecznej osób niepełnosprawnych /Activation through sport as a way of inclusion and social integration of people with disabilities/. Acta Universitatis Lodziensis. Folia Sociologica 56, 99-121. http://dx.doi.org/10.18778/0208-600X.56.07

Niedbalski, J. (2017). Wymiary konteksty i wzory karier. Proces stawania sięsportowcem przez osoby z niepetnosprawnościa fizyczna - analiza spolecznych mechanizmów (re)konstruowania tożsamości /Dimensions, contexts and patterns of careers. The process of becoming an athlete by people with physical disabilities - analysis of social mechanisms of (re) construction of identity/. Łódź: Wydawnictwo Uniwersytetu Łódzkiego. 
Niedbalski, J. (2019). Niepetnosprawność i osoby z niepetnosprawnościq /Disability and people with disability/. Łódź: Wydawnictwo Uniwersytetu Łódzkiego.

Nosal, P. (2015). Społeczne ujęcie sportu. (Trudne) definiowanie zjawiska i jego dyskurs /Social Perspective of Sport. (Difficulties With) Defining the Issue and Its Discourse/. Przeglad Socjologii Jakościowej, 11(2), 16-38.

Ostrowska A. (2009). Niepełnosprawność, rehabilitacja i integracja społeczna osób niepełnosprawnych /Disability, rehabilitation and social integration of people with disabilities/. In A. Ostrowska (Ed.), Socjologia medycyny: podejmowane problemy, kategorie analizy /The sociology of medicine: problems, categories of analysis/ (pp. 145-171). Wydawnictwo IFiS PAN.

Patel, D.R., Neelakantan, M., Pandher, K., Merrick, J. (2020). Cerebral palsy in children: a clinical overview. Translational Pediatrics 9(suppl. 1), 125-135. https://doi.org/10.21037/tp.2020.01.01

Purdue, D.E.J., Howe, P.D. (2012). See the sport, not the disability: exploring the Paralympic paradox. Qualitative Research in Sport, Exercise and Health, 4(2), 189-205. https://doi.org/10.1080/2159676X.2012.685102

Skibiński, A. (2018). Język jako narzędzie (auto)kreowania tożsamości /Language as a tool for (auto)-identity creation/. Scripta Neophilologica Posnaniensia, 7, 111-115. https://doi.org/10.14746/snp.2005.07.07

Sparkes, A., Smith, B., (2003). Men, sport, spinal cord injury and narrative time. Qualitative research, 3(3), 295-320. https://doi.org/10.1177\%2F1468794103033002

Urbanowicz, Z. (2012). Od interdyscyplinarnego do transdyscyplinarnego spojrzenia na niepełnosprawność /From Interdisciplinary to Trans-disciplinary Perspectives on Disability/. Ogrody Nauk i Sztuk, 2, 443-457.

Zdrodowska, M. (2016). Między aktywizmem akademią. Studia nadniepełnosprawnością /Between academy and activism. Disability studies/. Teksty drugie, 5, 384-403. DOI. 10.18318/td.2016.5.25.

Zielińska-Król, K. (2014). Rodzina w procesie wsparcia społecznego i zawodowego osoby niepełnosprawnej/The Support of the Family in the Process of Social and Professional Development of Disabled Persons/. Labor et Educatio, 2, 79-89.

Yin, R. K. (2014). Case Study Research Design and Methods (5th ed.). Thousand Oaks, CA: Sage.

Yoshida, K. (1993). Reshaping of self: a pendular reconstruction of self and identity among adults with traumatic spinal cord injury. Sociology of Health \& Illness, 15(2), 217-245. https://doi.org/10.1111/1467-9566.ep11346888

This is Open Access article distributed under the terms of CC-BY-NC-ND 4.0 International License. 